\title{
Cu-Zn-Sn-S Thin Films from Electrodeposited Metallic Precursor Layers
}

\author{
Raghu N. Bhattacharya* and J.Y. Kim
}

National Renewable Energy Laboratory, 1617 Cole Boulevard, Golden, Colorado 80401, USA

\begin{abstract}
Cyclic voltammogram of ionic liquid and metallic-salts in ionic liquids were recorded. $\mathrm{Cu} / \mathrm{Sn} / \mathrm{Zn}$ stacked layers were electrodeposited and subsequently sulfurized in a tube furnace in elemental sulfur at $550^{\circ} \mathrm{C}$. Thin films were characterized by X-ray diffraction, ICP-MS, and SEM. The device was characterized by I-V, QE and Mott-Schottky (capacitance-voltage) plot.
\end{abstract}

Keywords: $\mathrm{Cu}-\mathrm{Zn}-\mathrm{Sn}-\mathrm{S}$, thin films, electroplated, cyclic voltammogram.

\section{INTRODUCTION}

Photovoltaic (PV) solar electric technology will be a significant contributor to world energy supplies when reliable, efficient PV power products are manufactured in large volumes at low cost. A promising pathway to reducing PV cost is the use of thin-film technologies in which thin layers of photoactive materials are deposited inexpensively on large-area substrates. The primary chalcogenide semiconductor absorber materials currently used for thinfilm PV device applications are $\mathrm{Cu}(\mathrm{In}, \mathrm{Ga}) \mathrm{Se}_{2}$ and $\mathrm{CdTe}$. Despite the promise of these technologies, the toxicity of $\mathrm{Cd}$ and supply limitations for In and Te are projected to limit the production capacity of these existing chalcogen-based technologies to $<100 \mathrm{GWp}$ per year. This represents a small fraction of the world's growing energy needs, which are expected to double to $27 \mathrm{TW}$ by 2050 . Therefore, a lot of efforts have been made recently to explore new absorber materials with nontoxic and earth-abundant elements. One prominent example of the alternative solar cell materials is $\mathrm{Cu}_{2} \mathrm{ZnSnS}_{4}$ (CZTS). CZTS has a direct band gap of $1.45-$ $1.6 \mathrm{eV}$ and an optical absorption coefficient of around $10^{5}$ $\mathrm{cm}^{-1}[1,2]$. Recently several groups reported a CZTS thinfilms fabrication method using a variety of fabrication methods, namely sputtering [2-5], physical vapor deposition [6-11], a solution-particle approach [12-14], photochemical deposition [15], the sol-gel method [16], screen-printing [17], and electroplating [18-26]. The best conversion efficiency of the CZTS solar cell is reported to be $10 \%$ [1214]. The electroplated CZTS solar cell also demonstrated a respectable 7.3\%-efficient device [26].

Electroplating is a potentially suitable preparation method to obtain low-cost precursor films. The electrodeposition process could provide: (a) high-quality film with very low capital investment; (b) a low-cost, high-rate process; (c) use of very low-cost starting materials (e.g., lowpurity salts or solvents), based on automatic purification of the deposited materials during plating; (d) a large-area, continuous, multi-component, low-temperature deposition method; (e) deposition of films on a variety of shapes and

*Address correspondence to this author at the National Renewable Energy Laboratory, 1617 Cole Boulevard, Golden, Colorado 80401, USA; Tel: 303384-6477; Fax: 303-384-6432; E-mail: raghu.bhattacharya@nrel.gov forms (wires, tapes, coils, and cylinders); (f) controlled deposition rates and effective material use (as high as $98 \%$ ); and $(\mathrm{g})$ minimum waste generation (i.e., the solution can be recycled).

Most of the electrodeposited CZTS precursor films reported are prepared from aqueous electrolyte solutions. The electrodeposition of an element (e. g., Sn) that has a standard reduction potential more negative than the water reduction potential becomes very difficult due to the competition between electroplating of the desired element and water electrolysis. To avoid the water reduction issue, electrodeposition needs to be done using non-aqueous solvents with a large electrochemical window, like ionic liquids (ILs).

In this study, CZTS thin films have been prepared by electrodeposition of multilayered $\mathrm{Cu}-\mathrm{Sn}-\mathrm{Zn}$ metal films on $\mathrm{Mo} / \mathrm{glass}$ substrates from ionic liquid solvents. The electrodeposited thin-film precursor films are subsequently sulfurized in a tube furnace in an elemental sulfur environment.

\section{EXPERIMENTAL PROCEDURE}

In general, electrodeposition of $\mathrm{Cu}-\mathrm{Sn}-\mathrm{Zn}$ was performed sequentially from a Cu-plating solution, $\mathrm{Sn}$-plating solution, and $\mathrm{Zn}$-plating solution, respectively. First, a $\mathrm{Cu}$ layer was electrodeposited on a Mo/glass substrate from a Cu-plating solution, the second $\mathrm{Sn}$ layer was electrodeposited from a Sn-plating solution, and the third Zn layer was electrodeposited from a Zn-plating solution. The solution concentrations of each deposition solutions were $0.1 \mathrm{M}$. Fisher Scientific (FB300) and VWR (300V) power supplies were used to electrodeposit $\mathrm{Cu}-\mathrm{Sn}-\mathrm{Zn}$ thin films. All films were electrodeposited by applying constant current. $\mathrm{Cu}$ was plated at $-4.2 \mathrm{~mA} / \mathrm{cm}^{2}$ for 3 minutes, $S n$ was plated at -2.0 $\mathrm{mA} / \mathrm{cm}^{2}$ for 10 minutes and $\mathrm{Zn}$ was plated at $-1.7 \mathrm{~mA} / \mathrm{cm}^{2}$ for 8 minutes. The desired film composition was obtained by adjusting the film thickness of $\mathrm{Cu}, \mathrm{Sn}$ and $\mathrm{Zn}$. The films were electrodeposited in a vertical cell in which the electrodes (both working and counter) were suspended vertically from the top of the cell. Precursor films were prepared by employing a two-electrode cell in which the counter electrode was Pt gauze and the working electrode (substrate) was glass/Mo. The Mo film was about $1 \mu \mathrm{m}$ thick and was deposited by direct current (dc) sputtering. All 
chemicals were of Analar- or Puratronic-grade purity and were used as received. The film compositions were analyzed using Agilent Technolgies 7700 Series ICP-MS system. Xray diffraction (XRD) was performed by a Scintag X-ray machine using a Copper $\mathrm{K}_{\alpha}$ radiation at $\lambda=0.5456 \AA$. PV devices were completed by chemical-bath deposition of about $50 \mathrm{~nm}$ CdS, followed by radio frequency (RF) sputtering of $50 \mathrm{~nm}$ of intrinsic $\mathrm{ZnO}$ and $350 \mathrm{~nm}$ of $\mathrm{Al}_{2} \mathrm{O}_{3}$ doped conducting $\mathrm{ZnO}$. Bilayer $\mathrm{Ni} / \mathrm{Al}$ top contacts were deposited in an e-beam system.

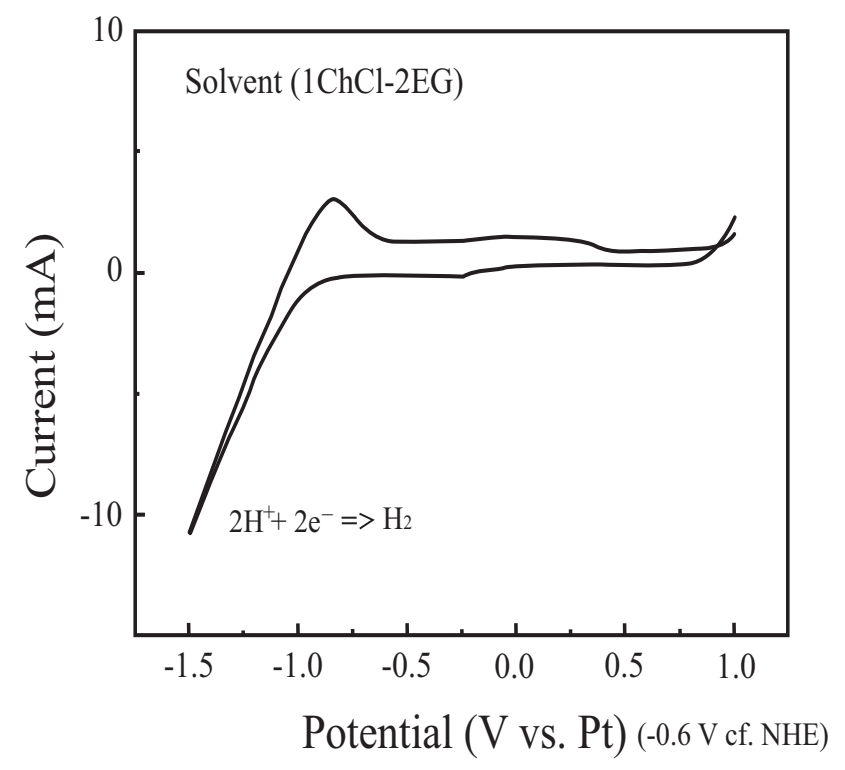

(a)

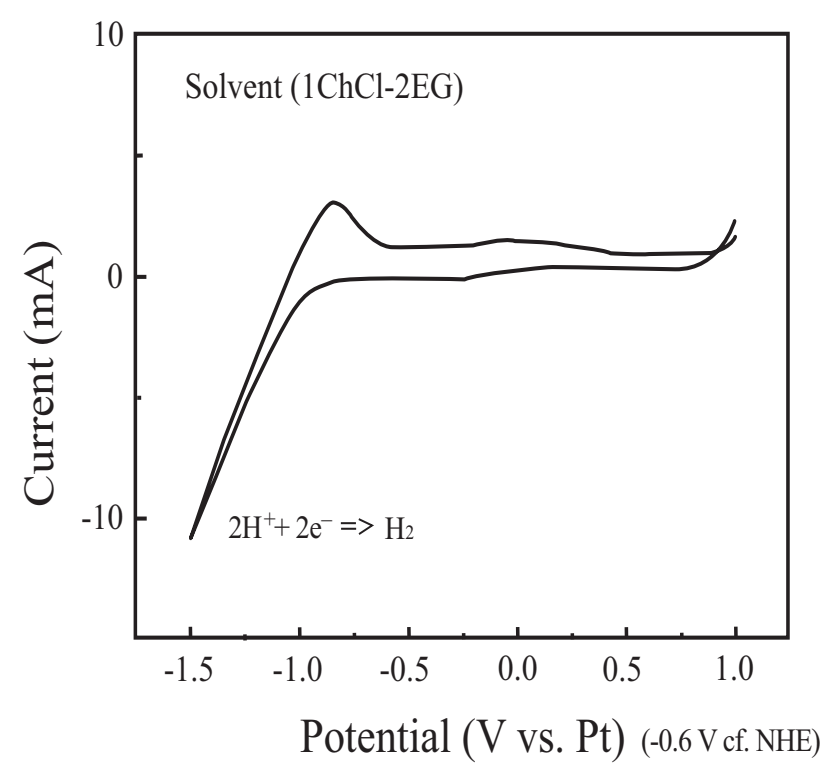

(F)

\section{RESULTS AND DISCUSSION}

Cyclic voltammograms (CVs) were obtained at $53^{\circ} \mathrm{C}$ with a scan rate of $50 \mathrm{mV} / \mathrm{s}$ using a potentiostat (Princeton, VCM4) with a 3-electrode system composed of Pt-working, Ptcounter, and Pt-quasi reference electrodes. The measurements were performed after the open circuit voltage of the electrochemical cell was stabilized (usually 1 hour). Fig. (1a) shows a CV curve of the choline chloride-based ionic liquid used in this study. The water reduction peak at $\mathrm{V}$ $\approx 0.9 \mathrm{~V} v s \mathrm{Pt}$, indicates a trace amount of water present in the

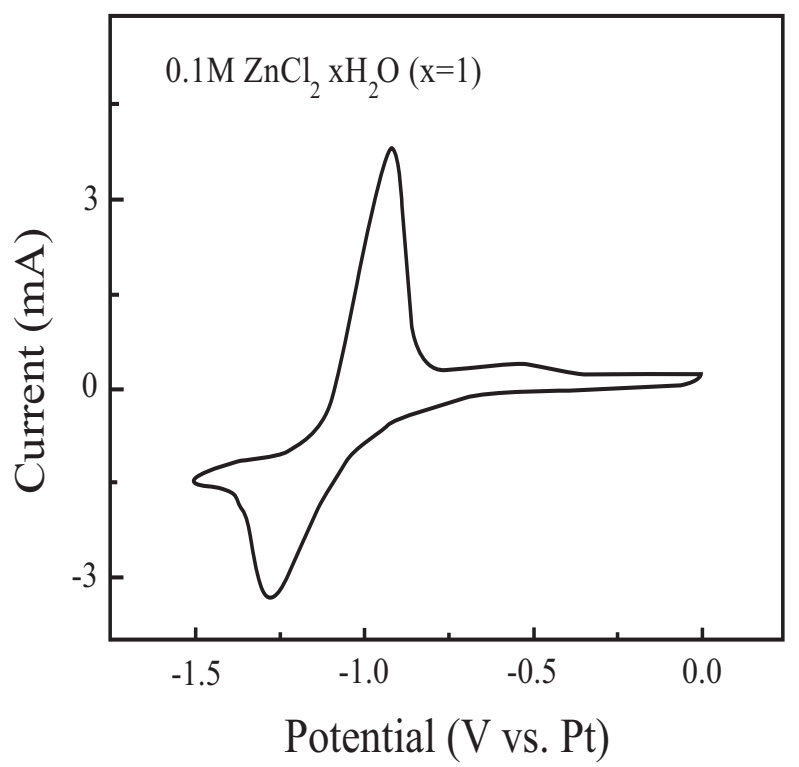

(E)

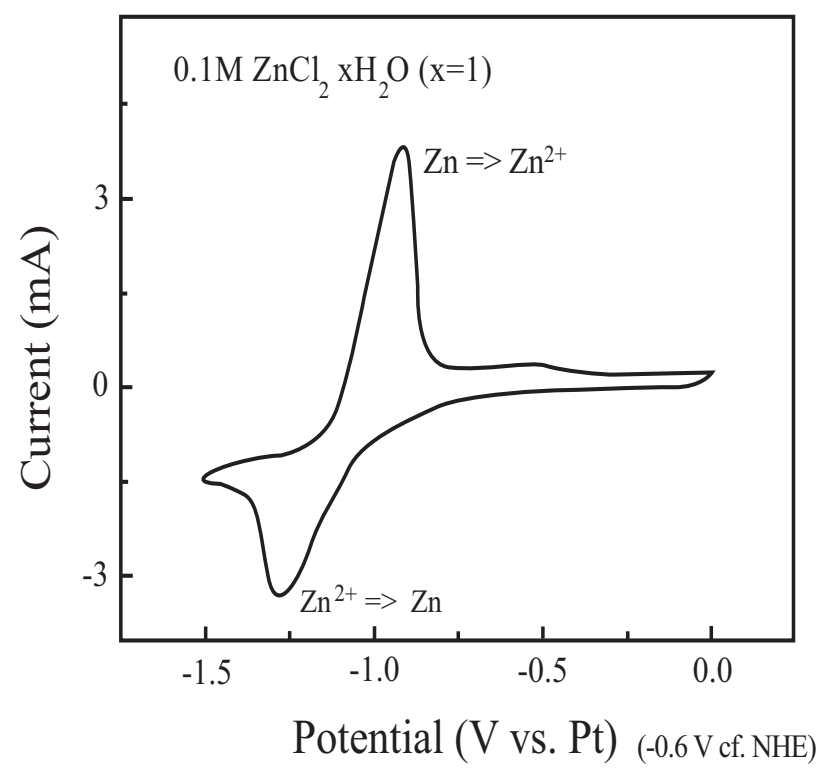

(G)

Fig. (1). (a) $\mathrm{CV}$ of the ionic liquid; (b) $\mathrm{CV}$ of $0.1 \mathrm{M} \mathrm{ZnCl}_{2}$ in ionic liquid; (c) $\mathrm{CV}$ of $0.1 \mathrm{M} \mathrm{SnCl}_{2}$ in ionic liquid; (d) $\mathrm{CV}$ of $0.1 \mathrm{M} \mathrm{CuCl}$. All $\mathrm{CVs}$ were performed at $53^{\circ} \mathrm{C}$. 


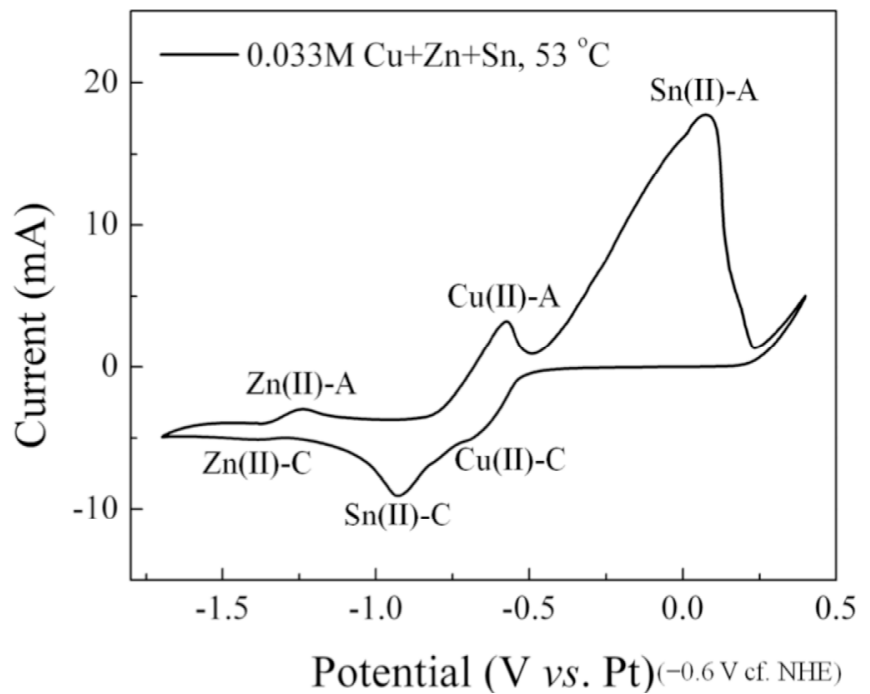

Fig. (2). $\mathrm{CV}$ of $0.033 \mathrm{M} \mathrm{CuCl}_{2}, \mathrm{ZnCl}_{2}$, and $\mathrm{SnCl}_{2}$ in ionic liquid at $53^{\circ} \mathrm{C}$.

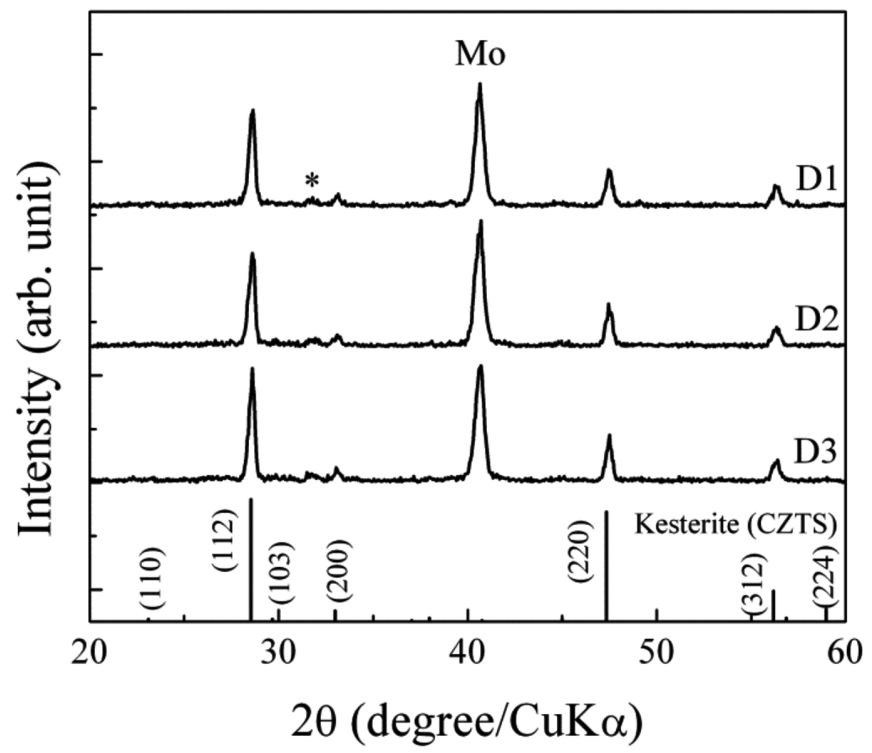

Fig. (3). X-ray diffractions of annealed $\mathrm{Cu}-\mathrm{Zn}-\mathrm{Sn}-\mathrm{S}$ thin films (D1, D2, and D3 samples were prepared under similar condition to check the reproducibility).

ionic liquid solvent. Fig. (1b) shows the CV curve of $0.1 \mathrm{M}$ $\mathrm{ZnCl}_{2} \mathrm{H}_{2} \mathrm{O}$ in choline chloride-based ionic liquid solution. The CV curve shows the Zn-reduction $\left(\mathrm{Zn}^{2+}+2 \mathrm{e}^{-}=>\mathrm{Zn}\right)$ and $\mathrm{Zn}$-oxidation $\left(\mathrm{Zn}=>\mathrm{Zn}^{2+}+2 \mathrm{e}^{-}\right)$peaks at $-1.28 \mathrm{~V}$ and $-0.92 \mathrm{~V}$ (vs $\mathrm{Pt}$ ), respectively. The standard reduction potential of $\mathrm{Zn}$ (II) $\left(\mathrm{Zn}^{2+}+2 \mathrm{e}^{-}=>\mathrm{Zn}\right)$ is $-0.76 \mathrm{~V}$ vs standard hydrogen electrode (SHE) in $1 \mathrm{M}$ aqueous solution at $25^{\circ} \mathrm{C}$ [27]. Fig. (1c) shows the CV curve of $0.1 \mathrm{M} \mathrm{SnCl}_{2} \mathrm{H}_{2} \mathrm{O}$ in choline chloride-based ionic liquid solution. The $\mathrm{CV}$ curve shows reduction $\left(\mathrm{Sn}^{2+}+2 \mathrm{e}^{-}=>\mathrm{Sn}\right)$ and oxidation $(\mathrm{Sn}=>$ $\mathrm{Sn}^{2+}+2 \mathrm{e}^{-}$) peaks of $\mathrm{Sn}$ at $-0.89 \mathrm{~V}$ and $0.06 \mathrm{~V}$ ( $v S \mathrm{Pt}$ ), respectively. The standard reduction potential of $\mathrm{Sn}$ (II) $\left(\mathrm{Sn}^{2+}\right.$ $+2 \mathrm{e}^{-}=>\mathrm{Sn}$ ) is $-0.14 \mathrm{~V}$ vs SHE in $1 \mathrm{M}$ aqueous solution at $25^{\circ} \mathrm{C}$ [27]. A larger reduction potential shift is observed for $\mathrm{Sn}$ compared with $\mathrm{Zn}$, when a Pt-quasi reference electrode is used in ionic liquid solvent. Fig. (1d) shows the CV curve of $0.1 \mathrm{M} \mathrm{CuCl}_{2}$ in choline chloride-based ionic liquid solution.
The CV curve shows two reduction peaks at $-0.25 \mathrm{~V}$ and $-0.57 \mathrm{~V}$, respectively. The standard reduction potential for $\mathrm{Cu}$ ions is $0.52 \mathrm{~V}$ and $0.34 \mathrm{~V}$ vs SHE in $1 \mathrm{M}$ aqueous solution at $25^{\circ} \mathrm{C}$ [27]. Fig. (2) shows the $\mathrm{CV}$ curve of $0.03 \mathrm{M}$ $\mathrm{CuCl}_{2}, 0.03 \mathrm{M} \mathrm{ZnCl}_{2}$, and $0.03 \mathrm{M} \mathrm{SnCl}_{2}$ in choline chloridebased ionic solution. The $\mathrm{CV}$ curve indicates that all metal ions could be co-deposited from the ionic liquid solvents. The significant reduction potential shifts of $\mathrm{Zn}, \mathrm{Sn}$, and $\mathrm{Cu}$ are attributed to Pt-quasi reference electrode and overpotential imposed by ionic liquid solvent. These reduction potential values are only useful to preset the deposition potential/current from the ionic liquid solution.

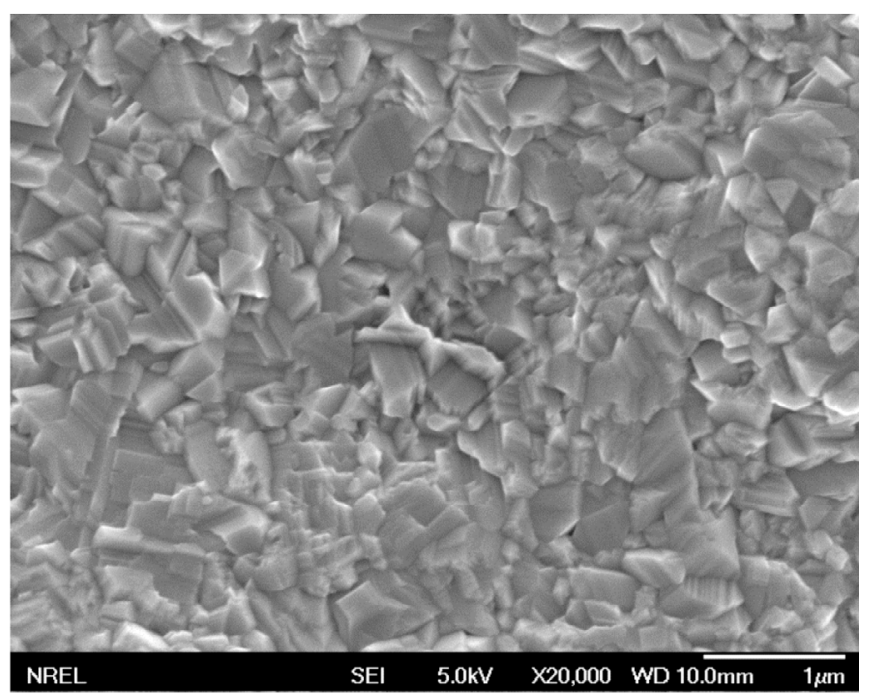

(a)

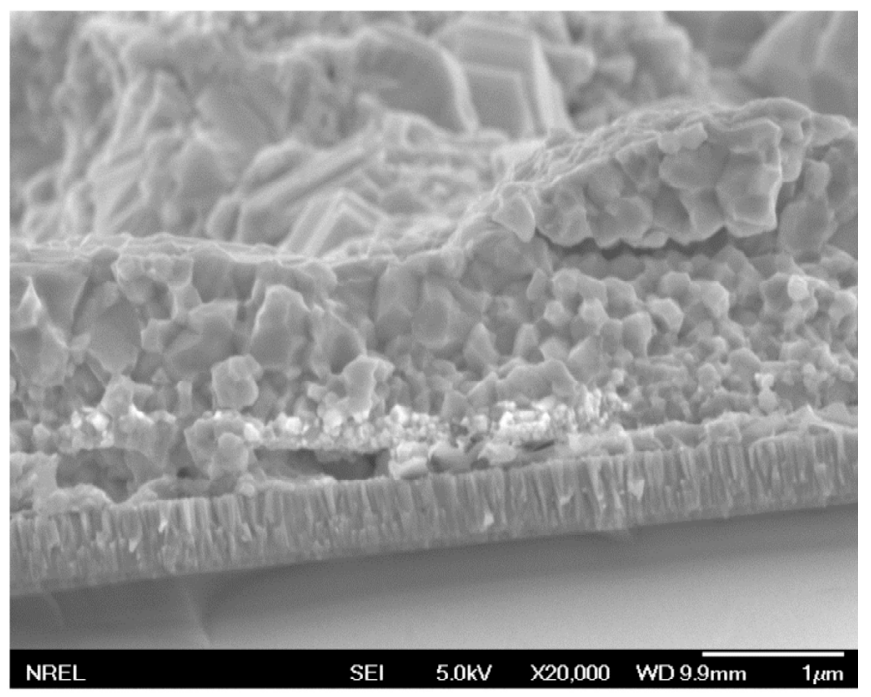

(b)

Fig. (4). (a) SEM surface morphology; (b) SEM cross-section of annealed CZTS thin films.

Fig. (3) shows the X-ray diffraction (XRD) patterns of three annealed CZTS thin films (D1, D2 and D3). The precursor electrodeposited $\mathrm{Cu} / \mathrm{Sn} / \mathrm{Zn}$ stacked layers were annealed in a tube furnace at $550^{\circ} \mathrm{C}$ in elemental $\mathrm{S}$ atmosphere for 60 minutes. All samples were prepared at 


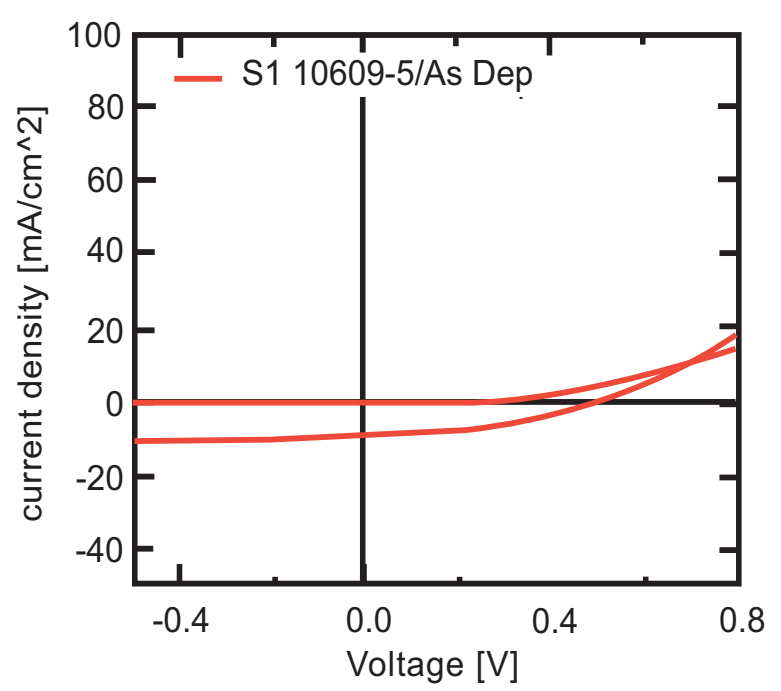

(a)

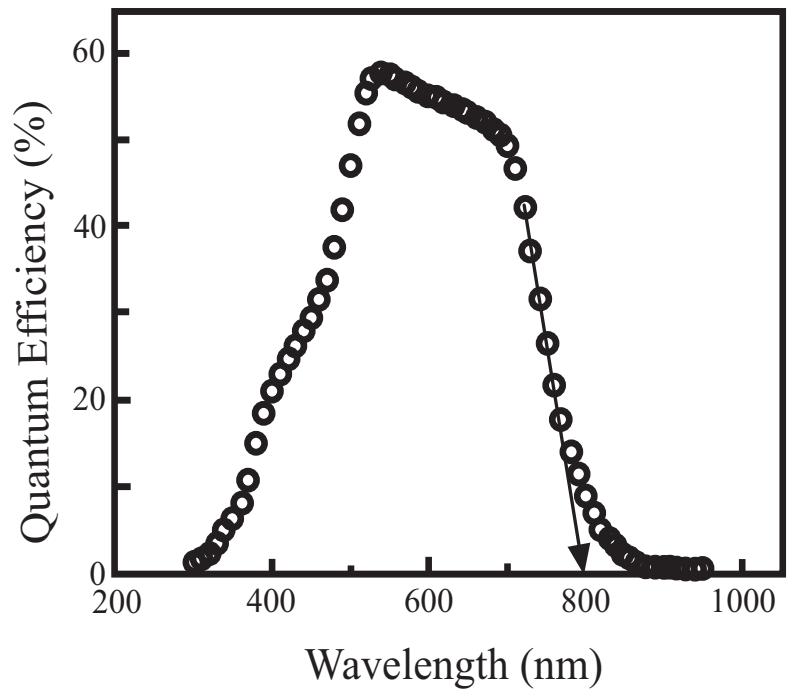

(b)

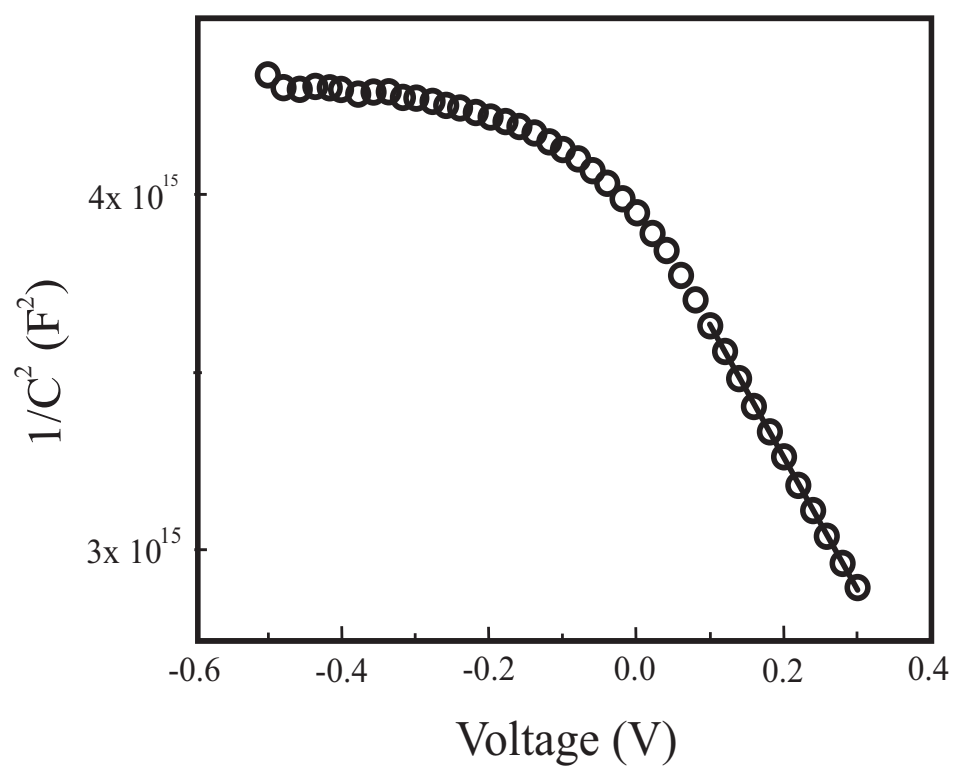

(F)

Fig. (5). (a) Current-voltage characteristics: $\mathrm{V}_{\mathrm{oc}}=0.51 \mathrm{~V}, \mathrm{~J}_{\mathrm{sc}}=9 \mathrm{~mA} / \mathrm{cm}^{2}$, fill factor $=37 \%$, and efficiency $=1.7 \%$; (b) $\mathrm{QE}$ characteristics of the device; (c) Mott-Schottky plot of the CZTS device.

same condition $\left(\mathrm{Cu}:-4.2 \mathrm{~mA} / \mathrm{cm}^{2}, 3 \mathrm{~min}, \mathrm{Sn}:-2.0 \mathrm{~mA} / \mathrm{cm}^{2}\right.$, $\left.10 \mathrm{~min}, \mathrm{Zn}:-1.7 \mathrm{~mA} / \mathrm{cm}^{2}, 8 \mathrm{~min}\right)$ to check the reproducibility of the deposition conditions. The precursor film compositions of the films, as analyzed by ICP-MS, were $\mathrm{Cu}: 47-49$ at\%; Zn:27-25 at\%, and Sn:26-24 at\%. As shown in Fig. (3), the XRD patterns are almost identical for all three samples representing Kesterite CZTS structure [joint committee on powder diffraction standards (JCPDS) \# 260575]. The small XRD peak at $32^{\circ}$ is attributed to the $\mathrm{Cu}_{1.95} \mathrm{~S}$ or $\mathrm{SnS}_{2}$ impurity phase [24]. The surface morphology and cross-sectional view (SEM) of a representative film annealed at $550^{\circ} \mathrm{C}$ for 60 minutes is shown in Fig. $(4 \mathbf{a}, \mathbf{b})$. The SEM as shown in Fig. (4a, b), indicate that films are crack-free and have a compact dense morphology. The cross-sectional 
view (Fig. 4b) of the film shows the film thickness is about $1.3 \mu \mathrm{m}$ and it has a very rough surface morphology. The grain size determined from the top-view and cross-sectional images ranged from about 100 to $500 \mathrm{~nm}$, and the grains exhibit sharp facets. This result indicates that we need to further optimize the deposition and processing conditions to obtain smooth and uniform films. Solar cell devices were fabricated from these absorber materials. The device efficiency (Fig. 5a) that resulted from the processed electrodeposited precursor film was only $1.7 \%$ with a respectable $\mathrm{V}_{\mathrm{oc}}(0.51 \mathrm{~V})$, but very poor $\mathrm{J}_{\mathrm{sc}}\left(9 \mathrm{~mA} / \mathrm{cm}^{2}\right)$ and poor fill factor (37.5). Very poor fill factor and $J_{\mathrm{sc}}$ are probably due to poor film morphology and presence of secondary phases. In this study, the samples were not treated with $\mathrm{KCN}$, so some conducting phases like $\mathrm{Cu}_{\mathrm{x}} \mathrm{S}$ (as shown by XRD) were present in the films. Chemical etching with $\mathrm{KCN}$ solution, which is known to remove $\mathrm{Cu}_{\mathrm{x}} \mathrm{S}$ phase effectively, will be incorporated in the future experiments. In addition, the partial pressure of vaporized $\mathrm{S}$ can be better controlled by using $\mathrm{H}_{2} \mathrm{~S}$ gas for forming $\mathrm{S}$ atmosphere rather than using elemental $\mathrm{S}$ as the source. Fig. (5b) displays the external quantum efficiency (EQE) spectrum of the device. The maximum quantum efficiency is as high as $60 \%$ at 550 $\mathrm{nm}$ and the $J_{\mathrm{sc}}$ calculated by integrating the spectrum $(\sim 10$ $\left.\mathrm{mA} / \mathrm{cm}^{2}\right)$ is in good agreement with the measured $J_{\mathrm{sc}}(9$ $\mathrm{mA} / \mathrm{cm}^{2}$ ). This EQE spectrum also reveals that the optical band gap of the CZTS thin film is $\sim 1.55 \mathrm{eV}(800 \mathrm{~nm})$. Fig. (5c) shows the Mott-Schottky (capacitance-voltage) plot of the CZTS solar cells. The charge carrier concentration $(p+$ $N_{A}$ ) calculated from the slope (linear fit) is $\sim 4 \times 10^{16} \mathrm{~cm}^{-3}$, which is significantly lower than the reported values of 3.81 x $10^{18} \mathrm{~cm}^{-3}$ for $0.49 \%$-efficient screen-printed CZTS thin films [17].

\section{CONCLUSION}

$\mathrm{CV}$ measurements were performed to understand the electrochemical behavior of the metal-salts in ionic liquid solutions. Electrodeposited CZTSS absorber layers are fabricated by annealing stacked $\mathrm{Cu} / \mathrm{Sn} / \mathrm{Zn}$ layers in the tube furnace in the presence of elemental sulfur. The absorber material used for the device fabrication has very low carrier concentration and so the device has only $1.7 \%$ efficiency. We are expecting to improve the device efficiency by processing the stacked layer in $\mathrm{H}_{2} \mathrm{~S}$ at high temperature.

\section{ACKNOWLEDGEMENTS}

The authors thank Clay DeHart (NCPV, NREL) for device fabrication. This work has been performed by an employee of the Alliance for Sustainable Energy, LLC, under contract number DE-AC36-08GO28308 with the U.S. Department of Energy. The United States Government retains a nonexclusive, paid-up, irrevocable, worldwide license to publish or reproduce the published form of this work, or allow others to do so, for United States Government purposes.

\section{CONFLICT OF INTEREST}

The authors declare that they have no competing interests.

\section{REFERENCES}

[1] Jimbo K, Kimura R, Kamimura T, et al. $\mathrm{Cu}_{2} \mathrm{ZnSnS}_{4}$-type thin film solar cells using abundant materials. Thin Solid Films 2007; 515: 5997-9.

[2] Ito K, Nakazawa T. Electrical and optical properties of stannitetype quaternary semiconductor thin films. Jpn J Appl Phys 1998; 27: 2094-7.

[3] Chalapathy RBV, Jung GS, Ahn BT. Fabrication of $\mathrm{Cu}_{2} \mathrm{ZnSnS}_{4}$ films by sulfurization of $\mathrm{Cu} / \mathrm{ZnSn} / \mathrm{Cu}$ precursor layers in sulfur atmosphere for solar cells. Sol Energy Mater Sol Cells 2011; 95: 3216-21.

[4] Tanaka T, Nagatomo T, Kawasaki D, et al. Preparation of $\mathrm{Cu}_{2} \mathrm{ZnSnS}_{4}$ thin films by hybrid sputtering. J Phys Chem Solids 2005; 66: 1978-81

[5] Seol JS, Lee SY, Lee JC, Nam HD, Kim KH. Electrical and optical properties of $\mathrm{Cu}_{2} \mathrm{ZnSnS}_{4}$ thin films prepared by rf-magnetron sputtering process. Sol Energy Mater Sol Cells 2003; 75: 155-62.

[6] Oishi K, Saito G, Ebina K, et al. Growth of $\mathrm{Cu}_{2} \mathrm{ZnSnS}_{4}$ thin films on $\mathrm{Si}(100)$ substrates by multisource evaporation. Thin Solid Films 2008; 517: 1449-52.

[7] Katagiri H, Sasaguchi N, Hando S, Hoshino S, Ohashi J, Yokota T. Preparation and evaluation of $\mathrm{Cu}_{2} \mathrm{ZnSnS}_{4}$ thin films by sulfurization of E-B evaporated precursors. Sol Energy Mater Sol Cells 1997; 49: 407-14.

[8] Katagiri H, Saitoh K, Washio T, Shinohara H, Kurumadani T, Miyajima S. Development of thin film solar cell based on $\mathrm{Cu}_{2} \mathrm{ZnSnS}_{4}$ thin films. Sol Energy Mater Sol Cells 2001; 65: 141-8.

[9] Grenet L, Bernardi S, Kohen $\mathrm{D}$, et al. $\mathrm{Cu}_{2} \mathrm{ZnSn}\left(\mathrm{S}_{1^{-}} \mathrm{Se}_{\mathrm{x}}\right)_{4}$ based solar cell produced by selenization of vacuum deposited precursors. Sol Energy Mater Sol Cells 2012; 101: 11-4.

[10] Wang K, Gunawan O, Todorov T, Shin B, Vhey SJ, Bojarczuk NA. Structural and elemental characterization of high efficiency $\mathrm{Cu}_{2} \mathrm{ZnSnS}_{4}$ solar cells. Appl Phys Lett 2011; 98: 051912.

[11] Salome PMP, Malaquias J, Fernandes PA, et al. Growth and characterization of $\mathrm{Cu}_{2} \mathrm{ZnSn}(\mathrm{S}, \mathrm{Se})_{4}$ thin films for solar cells. Sol Energy Mater Sol Cells 2012; 101:147-53.

[12] Mitzi DB, Gunawan O, Todorov TK, Wang K, Guha S. The path towards a high-performance solution-processed kesterite solar cell. Sol Energy Mater Sol Cells 2011; 95: 1421-36.

[13] Todorov TK, Reuter KB, Mitzi DB. High-Efficiency Solar Cell with Earth-Abundant Liquid-Processed Absorber. Adv Mater 2010; 22: E156-9.

[14] Barkhouse DAR, Gunawan O, Gokmen T, Todorov TK, Mitzi DB Device characteristics of a $10.1 \%$ hydrazine-processed $\mathrm{Cu}_{2} \mathrm{ZnSn}(\mathrm{Se}, \mathrm{S})_{4}$ solar cell. Prog Photovoltaics Res Appl 2012; 20: 6-11.

[15] Shin B, Zhu Y, Gunawan O, Bojarczuk NA, Chey SJ, Guha S. Thin film solar cell with $8.4 \%$ power conversion efficiency using an earth-abundant $\mathrm{Cu}_{2} \mathrm{ZnSnS}_{4}$ absorber. Prog Photovolt: Res Appl 2011; doi: 10.1002/pip.1174.

[16] Moriya K, Tanaka K, Uchiki H. Characterization of $\mathrm{Cu}_{2} \mathrm{ZnSnS}_{4}$ thin films prepared by photo-chemical deposition. Jpn J Appl Phys 2005; 44: 715-7.

[17] Zhou ZH, Wang Y, Xu D, Zhang Y. Fabrication of $\mathrm{Cu}_{2} \mathrm{ZnSnS}_{4}$ screen printed layers for solar cells. Sol Energy Mater Sol Cells 2010; $94: 2042-5$.

[18] Tanaka K, Oonuki M, Moritake N, Uchiki H. $\mathrm{Cu}_{2} \mathrm{ZnSnS}_{4}$ thin film solar cells prepared by non-vacuum processing. Sol Energy Mater Sol Cells 2009; 93: 583-7.

[19] Araki H, Kubo Y, Jimbo K, et al. Preparation of $\mathrm{Cu}_{2} \mathrm{ZnSnS}_{4}$ thin films by sulfurization of co-electroplated $\mathrm{Cu}-\mathrm{Zn}$ - $\mathrm{Sn}$ precursors. Phys Status Solidi C 2009; 61: 1266-8.

[20] Kurihara M, Berg D, Fisher J, Siebentritt S, Dale PJ. Kesterite absorber layer uniformity from electrodeposited pre-cursors. Phys Status Solidi C 2009; 6: 1241-4.

[21] Ennaoui A, Lux-Steiner M, Abou-Ras D, et al. $\mathrm{Cu}_{2} \mathrm{ZnSnS}^{4}$ thin film solar cells from electroplated precursors: Novel low-cost perspective. Thin Solid Films 2009; 517: 2511-4.

[22] Pawar SM, Pawar BS, Moholkar AV, et al. Single step electrosynthesis of $\mathrm{Cu}_{2} \mathrm{ZnSnS}_{4}$ (CZTS) thin films for solar cell application. Electrochimica Acta 2010; 55: 4057-61. 
[23] Chan CP, Lam H, Surya C. Preparation of $\mathrm{Cu}_{2} \mathrm{ZnSnS}_{4}$ films by electrodeposition using ionic liquids. Sol Energy Mater Sol Cells 2010; 94: 207-11.

[24] Schurr R, Holzing A, Jost S, et al. The crystallisation of $\mathrm{Cu}_{2} \mathrm{ZnSnS}_{4}$ thin film solar cell absorbers from co-electroplated $\mathrm{Cu}-\mathrm{Zn}-\mathrm{Sn}$ precursors. Thin Solid Film 2009; 517: 2465-8.
[25] Deligianni H, Ahmed S, Romankiw LT. The Next Frontier: Electrodeposition for Solar Cell Fabrication. Interface 2011; 20 : 47-53.

[26] Ahmed S, Reuter KB, Gunawan O, Gao L, Romankiw LT, Deligianni $\mathrm{H}$. A high efficiency electrodeposited $\mathrm{Cu}_{2} \mathrm{ZnSnS}_{4}$ solar cell .Adv Energy Mater 2012; 2: 253-9.

[27] CRC Handbook of Chemistry and Physics. David R, Ed. $74^{\text {th }}$ ed. Boca Raton: CRC Press 1993-1994.

(C) Bhattacharya and Kim; Licensee Bentham Open.

This is an open access article licensed under the terms of the Creative Commons Attribution Non-Commercial License (http: //creativecommons.org/licenses/by$\mathrm{nc} / 3.0 /$ ) which permits unrestricted, non-commercial use, distribution and reproduction in any medium, provided the work is properly cited. 